\title{
Fibrinolytic components of human uterine arterial and venous blood
}

\author{
A. V. P. MACKAY, P. C. DAS, P. R. MYERSCOUGH, AND J. D. CASH \\ From the Regional Blood Transfusion Centre, the Royal Infirmary, Edinburgh
}

SYNOPSIS The fibrinolytic components of uterine arterial and venous blood were studied in 14 patients undergoing various obstetrical and gynaecological procedures. There was a highly significant higher concentration of plasminogen activator, as measured by the euglobulin lysis time, and fibrin degradation products in the uterine venous blood.

Although there is abundant evidence to show that circulating plasminogen activator arises, at least in part, from the endothelial surface of certain blood vessels (Kwaan and McFadzean, 1956; Kwaan, Lo, and McFadzean, 1957; Todd, 1959; Messer, Celander, and Guest, 1962; Chakrabarti, Birks, and Fearnley, 1963; Neri Serneri, Rossi Ferrini, Masotti, Silvestrini, Paoletti, Nocentini, and Monaci, 1965), several authors have recently turned their attention to the dynamics of plasminogen activator release in local organ circulations. The interest in this work is twofold: it may expand our meagre understanding of the physiological role of the fibrinolytic enzyme system at the local tissue level (Astrup, 1966), but, it may also prove to be an important area of study in relation to the possible role of certain organs to act as generators of plasminogen activator destined for the systemic circulation. These aspects of the fibrinolytic enzyme system have been studied by two different experimental techniques. One group have approached the problem by quantitating the plasminogen activator content of various tissues (Astrup and Sterndorff, 1956; Albrechtsen, 1959; Coccheri and Astrup, 1961) and are now seeking to define more accurately the sites of localization and the rates of release of activator (Kwaan and Astrup, 1963, 1964), while the other group have studied the fibrinolytic components of blood entering and leaving organs. Thus, at the present time, evidence is available which indicates that the kidney may play a significant part in contributing to the systemic level of plasminogen activator (Buluk and Furman, 1962; Buluk and Malofiejew, 1963; Niewiarowski, Prokopowicz, Poplawski, and Worowski, 1964; Worowski, Niewiarowski, and Prokopowicz, 1964; Janusko, Furman, and Buluk, 1966).

Received for publication 6 February 1967
The following communication describes a series of experiments designed to demonstrate whether the uterus may also prove to be an organ from which plasminogen activator is released into the systemic circulation. Evidence will also be presented which suggests that active dissolution of fibrin is going on within the uterus.

\section{SUBJECTS}

Fourteen subjects were studied (aged 19-62 years, mean 41 years), 12 undergoing various gynaecological operations and two pregnant subjects.

Anaesthesia in all subjects was obtained by an epidural block, using $20 \mathrm{ml}$. $2 \%$ lignocaine plain, followed by $0.5 \%$ thiopentone with nitrous oxide and oxygen.

\section{MATERIALS}

anticoagulant Sodium citrate, B.P., 3.8\%.

BUFFERS

Barbiturate buffer Modified veronal buffer of $p \mathbf{H} 7 \cdot 4$, and ionic strength 0.15 (Owren, 1947).

Tris buffer $0 \cdot 15 \mathrm{M}$ solution of tris-(hydroxymethyl)amino-methane (Koch-Light Laboratories Ltd.) adjusted to $p \mathrm{H} 7 \cdot 8$.

Phosphate buffer $\quad 0 \cdot 1 \mathrm{M}$ at $p \mathrm{H} 7.6$.

FIBRINOGEN Human fibrinogen. supplied by the Kabi Pharmaceutical Company $(97 \%$ clottable, Batch No. 83164), was used.

A $1 \cdot 5 \mathrm{~g} / 100 \mathrm{ml}$. solution of this fibrinogen in tris buffer was stored in plastic tubes at $-20^{\circ} \mathrm{C}$. After thawing it was diluted to $0.15 \mathrm{~g} . / 100 \mathrm{ml}$. in tris buffer for use in fibrin plates assays.

THROMBIN Topical thrombin (Parke Davis \& Co., Batch No. 4-2073-1) was used. A solution of 50 units $/ \mathrm{ml}$. in tris buffer was prepared for fibrin plates, one of 5 units $/ \mathrm{ml}$. in barbiturate buffer for euglobulin lysis time estimations, and then one of 100 units $/ \mathrm{ml}$. in physiological saline for fibrinogen estimations. All solutions were stored at $-20^{\circ} \mathrm{C}$. in plastic tubes and were thawed immediately before use. 
STREPTOKINASE For plasminogen estimations, the preparation produced by Lederle Laboratories (batch no. 2201-66) was used. A solution was made up in phosphate buffer to give a concentration of 2,000 units $/ \mathrm{ml}$. immediately before use.

UROKINASE The standard reference preparation $(2,400$ Ploug units) produced by Leo Pharmaceuticals, Denmark (batch no. 63062) was used. Solutions of 3 units $/ \mathrm{ml}$. in tris buffer were prepared and stored at $-20^{\circ} \mathrm{C}$. in plastic tubes.

TRASYLOL Trasylol produced by Farbenjabriken Bayer AG (batch no. 2748) was used: $0 \cdot 1 \mathrm{ml}$. Trasylol solution containing 5,000 units $/ \mathrm{ml}$. was mixed with every $5 \mathrm{ml}$. sample of blood collected for fibrin degradation products estimation. (We have confirmed the findings of Marx, Weinzierl, Schwick, and Storiko, 1965) that this concentration is sufficient to inhibit all fibrinolytic activity.

SHEEP RED CELLS Sheep red cells, at least two weeks old, in Alsever's solution were obtained from Stayne Laboratories.

ANTI-FIBRINOGEN SERUM Rabbit anti-human fibrinogen serum was obtained from Behringwerke A.G., Germany (batch no. 806, A.C.).

GLASSWARE All glassware for fibrinolytic assay was siliconized by means of a $3 \%$ solution of I.C.I. M550 silicone in trichlorethylene.

SYRINGES AND NEEDLES Sterile plastic $20 \mathrm{ml}$. syringes with 20 gauge needles were used for obtaining blood samples under operating conditions.

\section{METHODS}

BLOOD SAMPLING AND PREPARATION FOR ASSAYS Samples of blood, each of $20 \mathrm{ml}$, were obtained, as nearly simultaneously as possible, by puncture of a uterine vein and artery, in that order, as soon as possible after the initial skin incision, with the minimum of tissue manipulation. The delay in blood sampling from the first incision ranged from 4 to 20 minutes (mean 9.5 minutes). The blood was immediately transferred to a series of tubes as follows: (1) $9 \mathrm{ml}$. to a siliconized glass centrifuge tube in melting ice, containing $1 \mathrm{ml}$. of citrate anticoagulant for fibrinolytic studies; (2) $5 \mathrm{ml}$. to an unsiliconized glass test-tube containing 500 units of Trasylol for F.D.P. assay; and (3) $2 \mathrm{ml}$. to a sequestrene tube for haematocrit recording.

Within five minutes of receiving the arterial sample the citrated plasma, in melting ice, was centrifuged at 3,400 r.p.m. for 20 minutes at $+4^{\circ} \mathrm{C}$. Euglobulin precipitation and inhibitor assays were then performed immediately. The samples in Trasylol were incubated in a water bath at $+37^{\circ} \mathrm{C}$. for 4 hours, the serum removed and the F.D.P. assay commenced.

EUGLOBULIN LYSIS TIME Euglobulin was precipitated and resuspended by the method described previously (Cash, 1966). Of the euglobulin solution, $0.24 \mathrm{ml}$. was transferred, in triplicate, to 3 in. $\times \frac{3}{8}$ in. siliconized test-tubes, clotted with $0.24 \mathrm{ml}$. of the thrombin solution ( 5 units $/ \mathrm{ml}$.) and the clots incubated at $+37^{\circ} \mathrm{C}$. in a water bath. The euglobulin lysis time was calculated as the time taken from the addition of the thrombin solution to complete lysis, recorded visually. The plasminogen activator content was expressed as activator units, derived from the formula $\frac{1300}{T}$ of Janusko and Dubinska, (1964), where $\mathrm{T}$ was the euglobulin lysis time in minutes.

FIBRIN PLATES Fibrinolytic activity of the euglobulin solutions and plasma samples was also determined on human fibrin plates (Astrup and Müllertz, 1952).

Fibrinogen, $10 \mathrm{ml}$., was clotted in a plastic petri dish (internal diameter $8.8 \mathrm{~cm}$.) with $0.2 \mathrm{ml}$. thrombin solution (50 units $/ \mathrm{ml}$. in tris buffer) on a level table. Twenty minutes after clotting, a $0.03 \mathrm{ml}$. drop of the test substance was placed, in triplicate, on the surface of the fibrin. The plates were incubated at $+37^{\circ} \mathrm{C}$. for 24 hours, and the product of the perpendicular diameters (in $\mathrm{mm}$.) of the lysed areas taken as a measure of the fibrinolytic activity.

INHIBITOR PLATES Human fibrin plates were prepared as above, but before clotting, $1 \mathrm{ml}$. of either plasma, or plasma diluted $\frac{1}{10}, \frac{1}{20}, \frac{1}{50}$, and $\frac{1}{10} \delta$ in physiological saline and added to the $10 \mathrm{ml}$. of fibrinogen, and thoroughly mixed. A control containing $1 \mathrm{ml}$. of saline was also set up in parallel. Thereafter $0.03 \mathrm{ml}$. drops of urokinase $(3.0$ units $/ \mathrm{ml}$. in tris buffer) were placed in triplicate on the fibrin film 20 minutes after clotting. The plates were incubated at $+37^{\circ} \mathrm{C}$. for 24 hours and the fibrinolytic activity measured as before.

FIBRINOGEN ASSAY The method of Ratnoff and Menzie (1951), as modified by Alkjaersig (1960), was used. The euglobulin was clotted in the presence of E.A.C.A. $\left(10^{-3} \mathrm{M}\right)$ to prevent lysis in vitro and left overnight at $+4^{\circ} \mathrm{C}$. to maximize coagulation.

PLASMINOGEN ASSAY The caseinolytic assay of Remmert and Cohen (1949), as modified by Alkjaersig, Fletcher, and Sherry (1959), was employed.

FIBRIN DEGRADATION PRODUCT ASSAY The products of fibrin degradation were assayed by a tanned red-cell haemagglutination inhibition assay, as devised by Merskey, Kleiner, and Johnson (1966). Serum samples were pretreated with thrombin $(100 \mathrm{units} / \mathrm{ml}$.) to remove all possible traces of residual fibrinogen and then adsorbed with normal washed packed sheep red blood cells ( $\mathrm{f}$ volume) at $+4^{\circ} \mathrm{C}$. for two hours to prevent non-specific reactions, before subsequent assay. These assays were carried out in a blind fashion so that the operator (P.C.D.) had no prior knowledge of the source of the serum sample.

\section{RESULTS}

Details of information concerning the subjects and the results of assays on the uterine artery and vein 
TABLE I

CLINICAL DETAILS OF THE PATIENTS STUDIED

\begin{tabular}{|c|c|c|c|c|}
\hline $\begin{array}{l}\text { Patient } \\
\text { No. }\end{array}$ & $\begin{array}{l}\text { Age } \\
\text { (yr.) }\end{array}$ & $\begin{array}{l}\text { Surgical } \\
\text { Procedure }\end{array}$ & $\begin{array}{l}\text { Time of Blood Sampling } \\
\text { after First Incision (min.) }\end{array}$ & Diagnosis \\
\hline $\begin{array}{l}1 \text { (P.S.) } \\
2 \text { (E.M.) } \\
3 \text { (A.M.) } \\
4 \text { (M.S.) } \\
5 \text { (A.S.) } \\
6 \text { (C.C.) } \\
7 \text { (M.P.) }\end{array}$ & $\begin{array}{l}37 \\
55^{1} \\
27 \\
37 \\
43 \\
45 \\
35\end{array}$ & $\begin{array}{l}\text { Hysterectomy } \\
\text { Hysterectomy } \\
\text { Gilliam suspension } \\
\text { Hysterectomy } \\
\text { Hysterectomy } \\
\text { Hysterotomy } \\
\text { Caesarian section }\end{array}$ & $\begin{array}{r}15 \\
20 \\
8 \\
12 \\
12 \\
8 \\
10 \\
10\end{array}$ & $\begin{array}{l}\text { Endometriosis } \\
\text { Uterine fibroids } \\
\text { Normal uterus } \\
\text { Uterine adenomyosis } \\
\text { Endometriosis } \\
\text { Uterine fibroids; pregnancy } \\
\text { Elective Caesarian section due to } \\
\text { contracted pelvis; not in labour }\end{array}$ \\
\hline $\begin{array}{l}8 \text { (P.G.) } \\
9 \text { (E.L.) } \\
10 \text { (C.N.) } \\
11 \text { (A.L.) }\end{array}$ & $\begin{array}{l}39 \\
43 \\
51 \\
19\end{array}$ & $\begin{array}{l}\text { Hysterectomy } \\
\text { Hysterectomy } \\
\text { Hysterectomy } \\
\text { Ovarian cystectomy }\end{array}$ & $\begin{array}{r}5 \\
10 \\
5 \\
4\end{array}$ & $\begin{array}{l}\text { Retroverted uterus; menorrhagia } \\
\text { Normal uterus; menorrhagia } \\
\text { Uterine adenomyosis } \\
\text { Uterus normal (no evidence of } \\
\text { malignancy in cyst) }\end{array}$ \\
\hline $\begin{array}{l}12 \text { (M.Q.) } \\
13 \text { (M.A.) } \\
14 \text { (A.S.) }\end{array}$ & $\begin{array}{l}42 \\
62^{1} \\
50^{1}\end{array}$ & $\begin{array}{l}\text { Hysterectomy } \\
\text { Hysterectomy } \\
\text { Hysterectomy }\end{array}$ & $\begin{array}{l}9 \\
8 \\
9\end{array}$ & $\begin{array}{l}\text { Uterine fibroids } \\
\text { Uterine adenomyosis } \\
\text { Carcinoma of body of uterus }\end{array}$ \\
\hline
\end{tabular}

TABLE II

FIBRINOLYTIC ASSAYS RESULTS

\begin{tabular}{|c|c|c|c|c|c|c|c|c|c|c|c|c|}
\hline \multirow[t]{2}{*}{$\begin{array}{l}\text { Case } \\
\text { No. }\end{array}$} & \multicolumn{2}{|c|}{$\begin{array}{l}\text { Euglobulin Lysis Time } \\
\text { Time (expressed as } \\
\text { activator units) }\end{array}$} & \multicolumn{2}{|c|}{$\begin{array}{l}\text { Fibrin Plate Assay } \\
\text { (euglobulin drops) } \\
\left(\text { area } \mathrm{mm} . .^{2}\right)\end{array}$} & \multicolumn{2}{|c|}{$\begin{array}{l}\text { Fibrin Plate Assay } \\
\text { (plasma drops) } \\
\left.\text { (area mm. } .^{2}\right)\end{array}$} & \multicolumn{2}{|c|}{$\begin{array}{l}\text { Euglobulin } \\
\text { Fibrinogen } \\
(\mathrm{mg} . / 100 \mathrm{ml} .)\end{array}$} & \multicolumn{2}{|c|}{$\begin{array}{l}\text { Euglobulin } \\
\text { Plasminogen } \\
\text { (c.u./ml. })\end{array}$} & \multicolumn{2}{|c|}{$\begin{array}{l}\text { F.D.P. } \\
(\mu \mathrm{g} . / 100 \mathrm{ml} .)\end{array}$} \\
\hline & Artery & Vein & Artery & Vein & Artery & Vein & Artery & Vein & Artery & Vein & Artery & Vein \\
\hline 1 & 30.9 & 50 & 696 & 900 & 195 & 380 & 176 & 191 & 3.95 & $4 \cdot 50$ & - & - \\
\hline 2 & 20.9 & $108 \cdot 3$ & 551 & 856 & 121 & 451 & 177 & 157 & 4.63 & 4.55 & 310 & 1860 \\
\hline 3 & 12.6 & $27 \cdot 6$ & 400 & 599 & 132 & 152 & 125 & 247 & 4.06 & 4.47 & - & - \\
\hline 4 & $7 \cdot 4$ & 38.2 & 484 & 1120 & 336 & 399 & 187 & 220 & $4 \cdot 80$ & 5.49 & - & $\overline{-}$ \\
\hline 5 & $15 \cdot 4$ & $44 \cdot 8$ & 529 & 782 & 100 & 400 & 120 & 107 & 3.84 & $3 \cdot 50$ & 620 & 3720 \\
\hline 6 & $2 \cdot 7$ & $7 \cdot 5$ & - & - & - & - & 137 & 160 & 3.40 & $3 \cdot 33$ & - & - \\
\hline 7 & $1 \cdot 4$ & $5 \cdot 5$ & 256 & 484 & 100 & 132 & 357 & 410 & $9 \cdot 50$ & 6.20 & - & - \\
\hline 8 & 16.2 & $24 \cdot 0$ & 647 & 729 & 379 & 552 & 305 & 320 & $2 \cdot 85$ & $3 \cdot 30$ & 620 & 2480 \\
\hline 9 & $5 \cdot 1$ & $26 \cdot 5$ & - & - & - & - & 275 & 265 & $1 \cdot 75$ & $2 \cdot 70$ & - & - \\
\hline 10 & 13.9 & $38 \cdot 2$ & 360 & 742 & - & - & 230 & 245 & $3 \cdot 35$ & $3 \cdot 40$ & 1240 & 3720 \\
\hline 11 & $21 \cdot 6$ & $40 \cdot 6$ & 600 & 840 & 80 & 132 & 218 & 220 & 3.60 & $4 \cdot 00$ & 1240 & 4960 \\
\hline 12 & $8 \cdot 5$ & $12 \cdot 6$ & 420 & 650 & 105 & 138 & 295 & 320 & 3.95 & 4.00 & 1860 & 3720 \\
\hline 13 & $27 \cdot 0$ & $44 \cdot 8$ & 885 & 900 & 360 & 506 & 350 & 350 & $4 \cdot 30$ & $4 \cdot 30$ & 2480 & 4960 \\
\hline 14 & $22 \cdot 8$ & $43 \cdot 3$ & 529 & 840 & 100 & 400 & 270 & 252 & 3.45 & 2.85 & 1240 & 3720 \\
\hline
\end{tabular}

plasmas are summarized in Tables I and II. There was a significantly shorter euglobulin lysis time in the blood from the uterine vein when compared with the uterine artery $(0.001>P<0.002)$. This could not be explained on the basis of a higher plasminogen and lower fibrinogen content of the uterine vein euglobulin solutions. These findings, together with the results of the fibrin plate assays, indicate a higher content of plasminogen activator in the uterine vein than in the artery. There was no detectable uterine arterio-venous difference in plasma urokinase inhibitor content, and the anterio-venous haematocrit results showed no evidence of haemoconcentration.

The results of the fibrin degradation product assays are also shown in Table II. There was a highly significantly increased content in the uterine vein $(\mathrm{P}<0.001)$.

\section{DISCUSSION}

The results of this study indicate that the human uterus may prove to be a potent source of plasimnogen activator destined for the systemic circulation and thus supports the conclusions of Maki, Nagayama, Sasaki, and Yoneya (1965) who compared the fibrinolytic components of blood from the cubital and uterine veins in three subjects. The patients studied by Maki's group, however, had received adrenaline, a powerful fibrinolytic stimulant (Biggs, Macfarlane, and Pilling, 1947; Truelove, 1951; Genton, Kern, and von Kaulla, 1961; Cash and Allan, 1967) before the spinal anaesthetic. It is presumed that the source of this activator was the uterine vascular endothelium, but Maki et al. (1965) have suggested that tissue activator, which is present in high concentrations in the uterus (Albrechtsen, 1959, Rasmussen, Roberts, and Astrup, 1964; Uszyński, Januszko, Uszyńska-Folejewska, and Buluk, 1965), may also gain access into the systemic circulation.

During the proteolysis of fibrinogen and fibrin by plasmin several large fragments are released 
known as fibrinogen/fibrin degradation products (Nussenzweig and Seligmann, 1960; Alkjaersig, Fletcher, and Sherry, 1962). The observed high uterine output of these substances would suggest that fibrin polymerization (coagulation) and its removal (fibrinolysis) is a continuous process within this organ. The uterinearterial and venous fibrinogen and plasminogen concentrations showed no evidence of consumption of these factors, however.

The physiological significance of these findings is not yet clear. The fact that 10 of the uteri were pathologically affected to such a degree as to require hysterectomy must be borne in mind, but, the observation of similar arterio-venous differences in two normal uteri (cases 3 and 11) and in two pregnant uteri (cases 6 and 7) would suggest that these phenomena were not dependent upon the presence of uterine pathology. It is conceivable that the anaesthetic may have had some causal role in this difference, and although Cuocolo, Esposito, and Spampinato (1965) found no systemic changes in fibrinolysis in man coincident with a wide range of anaesthestic procedures, this possibility cannot be ignored.

The small number of patients studied precludes any comment on the uterine arterio-venous differences at various stages of the menstrual cycle. However, there appeared to be no significant difference between the pre- and post-menopausal uteri, and we have assumed that it is unlikely that the uterine arterio-venous difference in plasminogen activator and fibrinogen fibrin degradation products is related to the reproductive activities of the uterus but may be a function of the known high vascularity of this organ (Faulkner, 1944).

The results of this investigation would indicate that further studies on regional arterio-venous differences of fibrinolysis are required and that the uterus, as well as the kidney, may prove to be a useful model for continued investigations of localized fibrinolysis and organ contribution to the systemic levels of plasminogen activator.

Our thanks are due to Dr. R. A. Cumming, Director, South East Scotland Regional Blood Transfusion Centre, for his support in this work, and to Professor R. J. Kellar, Dr. M. G. Kerr, Dr. J. Livingstone and Dr. M. M. Lees for their help in supplying the blood samples at operation. One of us (A.V.P.M.) was in receipt of an Edinburgh University Gunn Scholarship. This research programme has been supported by a grant from the Scottish Hospital Endowments Research Trust.

\section{REFERENCES}

Albrechtsen, O. K. (1959). Acta physiol. scand., 47, suppl. 165. Alkjaersig, N. (1960). Proceedings of the Conference on Thrombolytic Agents, 8-9 April 1960, edited by H. R. Roberts and J. D. Geraty, p. 136. Haematology Study Section (U.S.) Public Health Service.

-, Fletcher, A. P., and Sherry, S. (1959). J. clin. Invest., 38, 1086. -

Astrup, T. (1966). Fed. Proc., 25 (pt. I), 42. and Müllertz, S. (1952). Arch. Biochem., 40, 346.

, and Sterndorff, I. (1956). Acta physiol. scand., 37, 40.

Biggs, R., Macfarlane, R. G., and Pilling, J. (1947). Lancet, 1, 402.

Buluk, K., and Furman, M. (1962). Experientia (Basel), 18, 146.

-, and Malofiejew, M. (1963). Acta physiol. pol., 14, 371.

Cash, J. D. (1966). Brit. med. J., 2, 502.

-, and Allen, A. G. E. (1967). Brit. J. Haemat., in the press.

Chakrabarti, R., Birks, P. M., and Fearnley, G. R. (1963). Lancet, 1 , 1288.

Coccheri, S., and Astrup, T. (1961). Proc. Soc. exp. Biol. (N.Y.), $108,369$.

Cuocolo, R., Esposito, G., and Spampinato, N. (1965). Minerva anest., 31, 151.

Faulkner, R. L. (1944). Amer. J. Obstet. Gynec., 47, 185.

Genton, E., Kern, F., Jr., and von Kaulla, K. (1961). Amer. J. Med., 31, 564 .

Januszko, T., and Dubinska, L. (1964). Konferencja Pol. Tow. Hematol., Krynica, 1964.

- Furman, M., and Buluk, K. (1966). Thrombos. Diathes. haemorrh. (Stuttg.), 15, 554.

Kwaan, H. C., and Astrup, T. (1963). Arch. Path., 76, 595.

, (1964). J. Path. Bact., 87, 409.

- - (1956). Ibid., 15, 245.

Lo, R., and McFadzean, A. J. S. (1957). Clin. Sci., 16, 255.

Maki, M., Nagayama, M., Sasaki, K., and Yoneya, T. (1965). Tohoku J. exp. Med., 86, 43.

Merskey, C., Kleiner, G. J., and Johnson, A. J. (1966). Blood, 28, 1. Messer, D. L., Celander, D. R., and Guest, M. M. (1962). Circulat. Res., 11, 832.

Neri Serneri, G. G., Rossi Ferrini, P. L., Masotti, G., Silvestrini, E., Paoletti, P., Nocentini, P., and Monaci, M. (1965). G. Geront., 13, 551 .

Niewiarowski, S., Prokopowicz, J., Poplawski, A., and Worowski, K. (1964). Experientia (Basel), 20, 101.

Nussenzweig, V., and Seligmann, M. (1960). Rev. Hémat., 15, 451.

Owren, P. A. (1947). Acta med. scand., suppl. no. 194.

Rasmussen, J., Roberts, H. R., and Astrup, T. (1964). Surg. Gynec. Obstet., 118. 1277.

Ratnoff, O. D., and Menzie, C. (1951). J. Lab. clin. Med., 37, 316.

Remmert, L. F., and Cohen, P. P. (1949). J. biol. Chem., 181, 431.

Todd, A. S. (1959). J. Path. Bact., 78, 281.

Trulove, S. C. (1951). Clin. Sci., 10, 229.

Uszyński, M., Januszko, T., Uszyńska-Folejewska, R., and Buluk, K. (1965). Ginek. pol., 36, 315.

Worowski, K., Niewiarowski, S., and Prokopowicz, J. (1964). Thrombos. Diathes. haemorrh. (Stuttg.), 12, 87. 